\title{
Painless aortic dissection presenting with multisystem organ failure and owl's eyes sign of the spinal cord
}

\author{
Raymond Lam, ${ }^{1}$ Sara L Swenson, ${ }^{1}$ Thomas J Nuckton, ${ }^{1}$ Merrill Nisam
}

'Department of Medicine, California Pacific Medical Center, San Francisco, California, USA

${ }^{2}$ Department of Medicine, Marin General Hospital, Greenbrae, California, USA

\section{Correspondence to} Dr Thomas J Nuckton, nuckton@sutterhealth.org

Accepted 28 November 2017

\section{DESCRIPTION}

A 72-year-old woman presented to the hospital with 3 days of emesis, anorexia and generalised fatigue without any report of chest pain. Her physical examination was significant for mild confusion and bright red blood per rectum. On presentation she had bilateral lower extremity weakness, but was able to move both lower extremities; dorsalis pedis pulses were present bilaterally. Initial laboratory examinations demonstrated a white cell count of $16.7 \mathrm{~K} / \mu \mathrm{L}$, creatinine of $3.0 \mathrm{mg} / \mathrm{dL}$, aspartate aminotransferase/alanine aminotransferase of $1189 / 382 \mathrm{U} / \mathrm{L}$, lactate of $4.5 \mathrm{mmol} / \mathrm{L}$ and a troponin of $0.52 \mathrm{ng} / \mathrm{mL}$. ECG was unremarkable. An initial chest X-ray showed a dilated aortic arch and a modestly widened mediastinum. A CT scan of the chest was not done. Several hours after presentation, the patient was noted to have flaccid lower extremities and diminished distal pulses, but with no skin changes or signs of distal ischaemia. Duplex ultrasound of the lower extremities demonstrated biphasic waveforms of distal vessels with no areas of occlusion or evidence of embolisation. Transthoracic echocardiogram revealed a small pericardial effusion with grossly normal ventricular function; the aorta was not well visualised.

MRI of the spine, done to evaluate lower extremity weakness, demonstrated an 'owl's eyes' sign of the spinal cord-an abnormal hyperintense signal in the thoracic cord, extending from T6 to L1. The 'owl's eyes' sign is typically associated with spinal cord ischaemia and infarction. ${ }^{1}$ An axial cut from level T11 (figure 1) shows the sign well, with two enhancing, well-circumscribed, circular areas in the anterior horns of the spinal cord that resemble the two glowing eyes of an owl. The following day, the patient suddenly became hypotensive and obtunded and was transferred to the intensive care unit. Shortly after the transfer, she developed pulseless electrical activity and expired. Postmortem

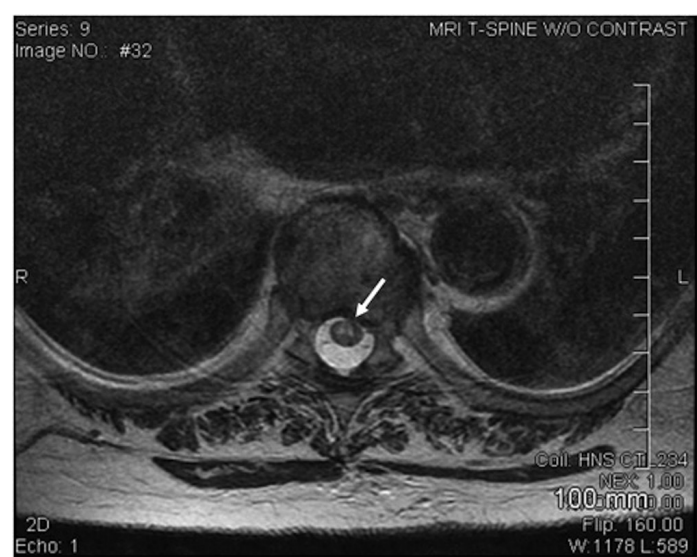

Figure 1 T2-weighted MRI of the spine, level T11, axial cut. Arrow indicates 'owl's eyes' sign: two enhancing, well-circumscribed, circular areas in the anterior horns of the spinal cord that resemble the two glowing eyes of an owl. The sign suggests spinal cord ischaemia and infarction.

examination revealed the cause of death as cardiac tamponade from a proximal thoracic aortic dissection (figure 2).

Two features of this case merit discussion. First, aortic dissection may not elicit the classic symptom of tearing chest pain. Lower extremity weakness and pulse deficits, other neurological changes, nausea and vomiting can all occur with painless aortic dissection. ${ }^{2}$ Presentation with multisystem organ involvement has been reported previously ${ }^{3}$ but is uncommon. Second, an 'owl's eyes' sign may be seen with acute aortic dissection. ${ }^{1}$ Its presence in our patient's case reflects infarction from a severe disruption of anterior blood flow to the spinal cord-the result of a profound dissection of the proximal thoracic aorta.

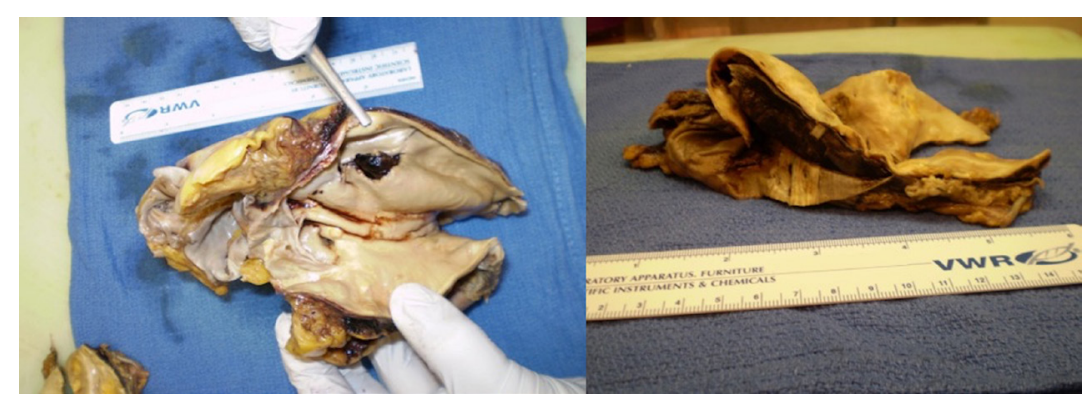

Figure 2 Postmortem pathology specimens demonstrating dissection of the proximal thoracic aorta (type B, descending). 


\section{Learning points}

Painless aortic dissection may be associated with a wide variety of associated findings on presentation, including those reflective of multisystem organ failure.

- An 'owl's eyes' sign on MRI of the spine can reflect a profound dissection of the proximal thoracic aorta involving compromise of the anterior blood supply to the spinal cord.

Contributors All authors: conception and design, acquisition of data or analysis, interpretation of data; drafting the article or revising it critically for important intellectual content; final approval of the version submitted and published; agreed to be accountable for the article and to ensure that all questions regarding the accuracy or integrity of the article are investigated and resolved.
Competing interests None declared.

\section{Patient consent Guardian consent obtained.}

Provenance and peer review Not commissioned; externally peer reviewed.

(C) BMJ Publishing Group Ltd (unless otherwise stated in the text of the article) 2017. All rights reserved. No commercial use is permitted unless otherwise expressly granted.

\section{REFERENCES}

1 Zamilute IA, Reis F, Silva Junior NA, et al. Neurological symptoms in a case of acute aortic dissection. Radiol Bras 2016;49:199-200.

2 Imamura H, Sekiguchi Y, Iwashita T, et al. Painless acute aortic dissection. - Diagnostic, prognostic and clinical implications. Circ J 2011;75:59-66.

3 Demircan A, Aksay E, Ergin M, et al. Painless aortic dissection presenting with acute ischaemic stroke and multiple organ failure. Emerg Med Australas $2011 ; 23: 215-6$.

Copyright 2017 BMJ Publishing Group. All rights reserved. For permission to reuse any of this content visit http://group.bmj.com/group/rights-licensing/permissions.

BMJ Case Report Fellows may re-use this article for personal use and teaching without any further permission.

Become a Fellow of BMJ Case Reports today and you can:

- Submit as many cases as you like

- Enjoy fast sympathetic peer review and rapid publication of accepted articles

- Access all the published articles

- Re-use any of the published material for personal use and teaching without further permission

For information on Institutional Fellowships contact consortiasales@bmjgroup.com

Visit casereports.bmj.com for more articles like this and to become a Fellow 